\title{
Peasant Migration and the Russian Working Class: Moscow at the End of the Nineteenth Century
}

Almost a hundred years have elapsed since Russian Marxists and Populists began their polemics over the social effects of industrialization, and seven decades have gone by since Bolsheviks and Mensheviks first clashed over the "ripeness" or maturity of the Russian working class. Nevertheless, debate continues to this day over the outlook of the prerevolutionary Russian working class.

No one disputes the fact that in the decades before 1917 a majorityalbeit a shrinking proportion-of factory workers came from the peasant estate (soslovie). Before the Stolypin legislation of 1906, a peasant who moved to the city or factory found it almost impossible to end his legal obligation to the village commune where he was born, and roughly 90 percent of the industrial workers in the city of Moscow were legally peasants. ${ }^{1}$ The question remains, however, whether the ties imposed by the passport system and obligatory land allotments were an empty formality: Were the "peasants" in Russian factories peasants in name only? How did the move to the cities and factories affect their ideas, values, or behavior?

Traditionally, two basic lines of interpretation have been offered. One, derived from the writings of Marx and Lenin, describes the move to the cities in positive terms, emphasizing the dissolution of patriarchal bonds and the growth of proletarian class consciousness. Despite differences in the pace of development, this process is seen as essentially similar to trends observed in Western capitalist countries. ${ }^{2}$ An opposite view is offered by many Western

1. According to the 1902 municipal census, 107,781 factory workers resided within the city limits of Moscow (Perepis' Moskvy 1902 goda, part 1, no. 2, table 2, pp. 10-11), as well as 104,899 in other nonfactory branches of manufacturing and 37,679 in transport. Of these workers, 92.7 percent of the first group, 90.3 percent of the second, and 94.6 percent of the third had been born elsewhere. The census does not indicate their soslovie, but other studies from the same years show that migrant workers were almost exclusively peasants (see, for example, P. M. Shestakov, Rabochie na manufakture "Emil' Tsindel" $v$ Moskve [Moscow, 1900], p. 20; at the Tsindel' cotton mill, one of Moscow's largest, 94.2 percent of the work force came from the peasant soslovie). The city's total population had grown from 753,000 in 1882 to 1.17 million in 1902; in both years, roughly threefourths of the total population had been born elsewhere.

2. A recent and subtle version of this argument is offered by Iu. I. Kirianov, "Ob oblike rabochego klassa Rossii," in Rossiiskii proletariat: Oblik, bor'ba, gegemoniia, ed. L. M. Ivanov (Moscow, 1970), pp. 100-140. This author gives considerable attention to the peculiarities of Russian development, and to the distinctions between various strata of the working class. He leaves no doubt, however, as to which workers were the bearers 
writers, who have underscored the negative, disruptive effects of factory employment, using such terms as alienation, anomie, and identity crisis. According to this argument, the Russian peasant worker was uprooted, bewildered, and prone to anarchic violence (buntarstvo) in the tradition of Pugachev. ${ }^{8}$ A uniquely Russian configuration of peasant unrest and industrial dislocation is thus seen as a source of worker militancy (and, implicitly, of the revolutions of 1905 and 1917). . $^{4}$

The disagreement between the two points of view is largely one of emphasis rather than hard fact. Proponents of the Leninist view acknowledge the existence of certain "vestiges of the feudal era" in the workers' mentality, but insist that the significance of these remnants was waning. Critics of the Leninist view, on the other hand, admit that a certain proportion of Russian workers managed to shed the traditions of the village and assimilate themselves to the new industrial order, but they maintain that this group was atypical of the working class as a whole. ${ }^{5}$ The present article will attempt to sort out these conflicting claims by reevaluating some of the historical evidence of the Russian workers' position and outlook.

The question of peasants' assimilation or nonassimilation to industrial life could be answered by studying such factors as family life, direct and

of revolutionary class consciousness-the "primitive" outlook of the peasant or semipeasant masses could not have produced a revolution (pp. 126-27).

3. See, in particular, Theodore Von Laue, "Russian Peasants in the Factory, 18921904," Journal of Economic History, 23, no. 1 (March 1961): 61-80. In Von Laue's words, "the peasant-worker's exertions were shorn of their spiritual wholeness. The connection between his inward motivation and his outward motions had been severed, the harmony broken. In this 'dehumanization of labor' lay the deepest source of his resentment against industrialization" (p. 80).

4. This point is emphasized by Leopold Haimson in his article "The Problem of Social Stability in Urban Russia, 1905-1917," Slavic Review, 23, no. 4 (December 1964): 619-42. In his view, newly-recruited workers "combined with their resentments about the painful and disorienting conditions of their new industrial experience a still fresh sense of grievance about the circumstances under which they had been compelled to leave the village." In the factories, such workers came into contact with a new generation of militant, city-born youths, and with Bolshevik agitation and propaganda; the result in St. Petersburg was a "spirit of buntarstvo" and a "polarization between workers and educated, privileged society."

5. In a provocative review of several recent Soviet publications, Reginald Zelnik suggests that "a relatively high proportion of hereditary proletarians ... tended to be a function of industrial stagnation"-that is, that each new cycle of economic growth required the recruitment of new cadres of inexperienced workers from the countryside, thereby tending to submerge the "proletarian" workers in a semiproletarian mass. Zelnik goes on to describe the working class as having a "uniquely volatile and dynamic mixed consciousness," in which agrarian grievances were compounded with those of the city and factory ("Russian Workers and the Revolutionary Movement," Joumal of Social History, 6, no. 2 [Winter 1972-73]: 217-19). 
indirect links to agriculture, duration of factory employment, or patterns of behavior and association in the cities. The present study, however, will restrict itself to a single body of evidence, dealing with the duration of peasants' residence at factories and in the city of Moscow. In this way, I hope to determine to what extent peasants put down permanent roots in their new environment: What proportion of the peasants departed after a few years, to be replaced by new migrants from the countryside?

Moscow was chosen for study, not only because of its size and industrial significance, but because the phenomenon of peasant migration was more prominent there than in any other major industrial center. In 1897, Moscow city and province had more outsiders (prishlye, literally "those who came" from places outside the city or $u e z d$ where the census-takers found them) living within their borders than any other city or province in European Russia. ${ }^{6}$ Over 75 percent of these migrants were peasants, drawn mostly from the seven provinces which surrounded Moscow-Tver, Yaroslavl, Vladimir, Riazan, Kaluga, Tula, and Smolensk. The other industrial centers in these provinces drew their workers from the same sources and, like Moscow, were engaged mostly in textile manufacturing and other light industry. Thus, it is reasonable to suggest that the patterns which will be described in the following pages would also be found in adjacent industrial centers as well. On the other hand, workers in other parts of the Russian Empire generally traveled further to find factory employment and were a more heterogeneous mass in terms of language, nationality, and religion; Moscow's patterns would probably be less relevant to their experience.

Moscow was also the scene of one of the earliest studies of factory labor -the oft-quoted work of E. M. Dement'ev. ${ }^{7}$ In his inspection of factories in three southern uezdy of Moscow province in 1884-85, Dement'ev tried to determine whether workers were leaving the factories to work seasonally in agriculture. He observed that mechanized factories could not afford to shut down for the summer, and that year-round employment was the predominant pattern in all but the most backward branches of industry. ${ }^{8}$ Data for the whole of Moscow province, moreover, indicated that more than one-fifth of all factory workers had spent more than twenty-five years at their jobs. ${ }^{9}$

6. A. G. Rashin, "Dinamika chislennosti $i$ protsessy formirovaniia gorodskogo naseleniia Rossii v XIX-nachale XX vv.," Istoricheskie zapiski, no. 34, 1950, p. 71.

7. E. M. Dement'ev, Fabrika, chto ona daet naseleniiu ichto ona "t nego beret (Moscow, 1893), pp. 1-57. Dement'ev's research was part of the Moscow zemstvo's comprehensive survey of factory conditions throughout Moscow province, and his findings were first published in Sbornik statisticheskikh svedenii po Moskovskoi gubermii, Otdel Sanitarnyi, vol. 4, no. 2 (Moscow, 1893).

8. Dement'ev, Fabrika, p. 6 ff.

9. Sbomik statisticheskikh svedenii po Moskovskoi gubernii, Otdel Sanitarnyi, vol. 4, no. 1 (Moscow, 1890), p. 287. 
Dement'ev concluded that there existed "a class of workers without a shelter of their own, having in fact no property . . . living from day to day" and totally alien to the countryside. ${ }^{10}$ Many other students of this question, from Lenin down to the present, have repeated Dement'ev's figures and accepted his rather sweeping conclusions. A closer examination of the evidence suggests, however, that rural ties may have been more widespread and persistent than Dement'ev recognized. Dement'ev's figures were compiled in a period of economic depression, and the smaller cohort of newly-recruited workers may have led him to overstate the importance of industrial "veterans." In subsequent periods of rapid economic expansion, the proportion of "green" recruits without previous factory experience would undoubtedly soar. ${ }^{11}$

Whether or not this was so, statistics on the duration of factory employment provide only indirect evidence of workers' ties to the village. Dement'ev himself acknowledged that industrial veterans were often concentrated in occupations with the highest rates of seasonal departures. ${ }^{12}$ As table 1 indicates, the same pattern was found among male textile workers in Moscow city in 1881. Occupations with the highest proportions of industrial veterans all show high rates of summer departure, and the three groups with the highest departure rates-hand weavers of wool, silk, and cotton-are all above average in the proportion of long-term workers. Long-term employment per se was evidently not an obstacle to maintaining rural ties.

Even workers who stayed year-round at factories could be visited by their relatives, and could return to the countryside at Easter and other holidays. Contemporary accounts of factory life suggest that this was a routine practice. Dement'ev, for example, describes a type of cart which was used to provide low-cost transportation to workers returning home at Easter. ${ }^{13}$ In some areas, workers who made such a journey were expected to bring back "gifts" of produce for their foremen, and were punished for failing to do so. ${ }^{14}$

Other sources describe workers as returning to their native villages because of age, infirmity, and unemployment. In 1885, a bad year for the textile industry, zemstvo statisticians in Moscow province noted that many workers who had lost their jobs were returning to the countryside, even though they

10. Dement'ev, Fabrika, p. 46.

11. According to figures compiled by the Ministry of Finance, the number of factory workers in Moscow city and province increased from 164,560 to 259,424 between 1879 and 1901. The greatest part of this increase occurred during the industrial boom of the "Witte years" from 1895 to 1900 . See Ministerstvo finansov, Departament torgovli i manufaktur, Ukasatel' fabrik i zavodov evropciskoi Rossii, comp. P. A. Orlov (St. Petersburg, 1881); and Spisok fabrik i zavodov curopeiskoi Rossii [for 1901] (St. Petersburg, 1903).

12. Dement'ev, Fabrika, p. 49.

13. Ibid., p. 35.

14. K. A. Pazhitnov, Polozhenie rabochego klassa v Rossii, vol. 2 (Leningrad, 1924), pp. 179-80, referring specifically to Moscow province. 
Table 1. Length of Employment and Rates of Summer Departure in Separate Occupational Groups, Moscow City, 1881

\begin{tabular}{lcc}
\hline \multicolumn{1}{c}{ Occupation } & $\begin{array}{c}\text { Males } \\
\text { with 15 or more } \\
\text { years' experience } \\
\text { in factories } \\
\text { (Percent) }\end{array}$ & $\begin{array}{c}\text { Males } \\
\text { departing } \\
\text { in summer } \\
\text { months } \\
\text { (Percent) }\end{array}$ \\
\hline Warpers & 82 & 62 \\
Dye-Printers (Hand) & 70 & 55 \\
Broadcloth-weavers & 59 & 58 \\
Silk-weavers & 59 & 75 \\
Machine-loom operators & & 57 \\
(Samotkachi) & 58 & 91 \\
Wool-weavers & 54 & 96 \\
Cotton-weavers & 47 & 40 \\
Carpenters & 35 & 59 \\
Engravers & 27 & 67 \\
Bleachers, dyers & 24 & 49 \\
Pressers & 24 & 55 \\
Miscellaneous & 23 & 63 \\
Spinners & 23 & 37 \\
Shearers & 19 & 67 \\
Scutchers & 9 & 71 \\
Overall average & 45 &
\end{tabular}

Source: P. A. Peskov, Sanitarnoe issledovanie fabrik po obrabotke voloknistykh veshchestv $v$ gorode Moskve, Trudy komissii uchrezhdennoi g. Moskovskim General-Gubernatorom kn. V.A. Dolgorukovym dlia osmotra fabrik i zavodov v Moskve, no. 1 (Moscow, 1882), p. 134.

were no longer accustomed to agricultural work. ${ }^{15}$ Precise statistics on such movement are unavailable. The same is true with respect to illness and disability; factory doctors are quoted as complaining that ill workers often returned to the village instead of seeking care in the infirmary, ${ }^{16}$ but comprehensive figures were not gathered. ${ }^{17}$

A movement of older workers away from city and industry was noted by many authors, among them P. M. Shestakov, whose study of the Tsindel' cotton mill was the most detailed of its kind. He observed that, although many workers quit or were laid off because they were physically unable to continue, others left at age 40 to assume personal charge of their households in the country. At this age, Shestakov hypothesized, workers were stepping into the

15. Statisticheskii ezhegodnik Moskovskoi gubernii za $1885 \mathrm{~g}$. (Moscow, 1886), pp. 78-79, 128.

16. F. P. Pavlov, Za desiat let praktiki (Moscow, 1901), p. 70.

17. On the other hand, V. I. Romashova, using the archive of the Kol'chugin brass and copper works in Moscow (GIAMO, f. 335), has concluded that the families of most disabled workers resided not in the country but at the factory; she does not give concrete figures. ("Obrazovanie postoiannykh kadrov rabochikh $\mathbf{v}$ poreformennoi promyshlennosti Moskvy," in Rabochii klass i rabochee dvizhenie, 1861-1917 [Moscow, 1966], pp. 161-62.) 
shoes of their fathers, who had died or were no longer able to head the households themselves. ${ }^{18}$

If a significant proportion of factory workers retained close ties to the village, and returned there in time of need, this fact should be reflected in statistics on turnover in the industrial work force. Unfortunately, as noted above, the industrial studies described here include few such statistics. The same must be said of municipal censuses, which provide at best incomplete information about broad (and ill-defined) occupational groups. Furthermore, the published census results often omit the particular combinations of variables (for example, occupation and duration of residence) which would be most useful for present purposes.

Overall census data can, however, be used to trace departures from the city of Moscow. Although data on factory workers' migration patterns are not available, they can be inferred from statistics on migrants and peasants-the two overlapping categories from which, as noted earlier, the vast majority of factory workers was recruited. The remainder of this article will use material from two municipal censuses of Moscow, taken in 1882 and $1902,{ }^{10}$ to determine how long peasant migrants tended to reside in Moscow city, and whether they settled permanently there. First, the overall pattern of movement into and away from the city will be considered, and then statistics relating to specific groups within the population will be examined.

A crude estimate of movement away from Moscow can be obtained by comparing the annual influx of migrants with the overall increase in the city's population. Of all persons counted in the 1882 census, 100,530 , or 13 percent, had arrived in the city during the preceding year. The comparable figure in 1902 was over 113,000 , just under 10 percent of the city's population. Statisticians estimated Moscow's overall population growth in the years preceding

18. Shestakov, Rabochie na manufakture, p. 22. Further evidence of workers' ties to the village can be found in Shestakov's investigation of landholding. Fully 90 percent of the workers he interviewed possessed an allotment of land; of the remaining 10 percent, three-fourths came from families which had received no land at the time of emancipation. Although one-third of the workers could not supply detailed information about their land holdings, all but one knew exactly how many horses and cows their household possessed. It should be noted that these workers were not, in the main, newly-arrived from the villages, but had spent an average of 10.3 years in factory employment (ibid., pp. $19,25,26)$.

19. Perepis' Moskvy 1882 goda, nos. 1-3 (Moscow: Gorodskoi statisticheskii komitet, 1884-86) ; Perepis' Moskvy 1902 goda, part 1, nos. 1-3 (Moscow: Statisticheskii otdel Moskovskoi gorodskoi upravy, 1904-6). The national census of 1897 (Pervaia vseobshchaia perepis' nascleniia Rossiiskoi imperii, $1897 \mathrm{~g}$., vol. 24, notebooks 1-2 [Moscow, 1901-4]) and the municipal one of 1871 (Statisticheskie svedeniia o zhiteliakh goroda Moskvy, po perepisi 12 dek. $1871 \mathrm{~g}$. [Moscow, 1874]) were both examined during the preparation of this article, but were found to lack the particular categories of information which were most relevant to the present discussion. 
Table 2. Migrants Residing in Moscow City, 1882 and 1902, By Duration of Residence

\begin{tabular}{|c|c|c|c|c|}
\hline \multirow[b]{2}{*}{ Years of residence } & \multicolumn{2}{|c|}{1882} & \multicolumn{2}{|c|}{1902} \\
\hline & Total & $\begin{array}{l}\text { As percent } \\
\text { of one year's } \\
\text { in-migration }\end{array}$ & Total & $\begin{array}{l}\text { As percent } \\
\text { of one year's } \\
\text { in-migration }\end{array}$ \\
\hline Less than one year & 100,530 & - & 113,715 & - \\
\hline One year & 43,672 & 43 & 52,768 & 46 \\
\hline Two years & 40,425 & 40 & 56,088 & 49 \\
\hline Three to five years & 76,168 & & 124,589 & \\
\hline (yearly average) & 25,389 & 25 & 41,526 & 37 \\
\hline Six to ten years & 87,604 & & 134,201 & \\
\hline (yearly average) & 17,520 & 17 & 26,840 & 24 \\
\hline Eleven to fifteen years & 61,360 & & 83,466 & \\
\hline (yearly average) & 12,272 & 12 & 16,693 & 15 \\
\hline Sixteen to twenty years & 41,633 & & 75,837 & \\
\hline (yearly average) & 8,326 & 8 & 15,167 & 13 \\
\hline More than twenty years & 87,927 & - & 134,304 & - \\
\hline Total migrant populatione & 556,910 & & 781,067 & \\
\hline $\begin{array}{l}\text { Total city-born of whom, } \\
\text { ages } 20 \text { and above }\end{array}$ & 196,559 & & 297,027 & \\
\hline
\end{tabular}

a Excludes foreigners.

b Suburban districts were not included in the 1882 census, and are here excluded from 1902 results as well for the sake of consistency. These districts had a total population of 20,361 Moscow-born and 61,469 migrants in 1902 .

c Includes "unknown duration" (27,591 in 1882, 6,119 in 1902).

Sources: Perepis' Moskvy 1882 g., no. 2, pp. 41-42; Perepis' Moskvy 1902 g., part 1, no. 1 , table 5 , p. 11 (my calculation).

both censuses at roughly 20,000 persons ( 2.5 percent) per annum; this figure included both natural increase (births exceeded deaths by 2,500 per annum in the years 1897-1902) and net increase through migration (estimated at 17,000 per annum ). ${ }^{20}$ If more than 113,000 persons moved to Moscow in 1902 and the net population growth was 20,000 , then some 90,000 persons must have moved away from the city in that year.

Precisely who were these 90,000 ? The census results suggest that many were migrants who had lived in Moscow for only a few years. Table 2 lists the duration of residence of all migrants counted in the censuses of 1882 and 1902. If the influx of migrants in 1901 was typical of other years ${ }^{21}$ - that is, approximately the same number moved to the city in 1899,1898 , and so forth-then the top line of table 2 can be compared with each successive

20. V. Mikhailovskii, "Glavneishie predvaritel'nye dannye perepisi goroda Moskvy, Chast' 1," Izvestiia Moskovskoi gorodskoi dumy, 26, no. 9 (1902): 9-10, 24.

21. In fact, because of worsening economic conditions, in-migration in both years may have been less, and out-migration greater, than at other times. The statistician who directed the 1902 census concluded that population increase had been greatest from 1897 to 1900 , and had fallen off somewhat in 1882 and 1902 (ibid., p. 10). 
line to determine the rate of out-migration. In other words, if 113,000 migrants moved to Moscow in 1900, more than half that group was no longer living in the city by 1902. If the influx was the same in 1897, only 37 percent of that group was still living in Moscow in 1902, and so on down the table. By the time we reach the "sixteen to twenty years" group, we find that each year's cohort of migrants is less than one-sixth as great as the in-migration of 1901. If the initial assumption of a steady rate of in-migration is correct, then five migrants must have died or moved away for every one who remained in the city for sixteen to twenty years.

Because the two censuses were taken exactly twenty years apart, a further computation of out-migration is possible. The total migrant population of 1882 can be compared with the "more than twenty years' residence" group of 1902. Of 555,910 migrants residing in Moscow in the earlier year, 136,091 (24 percent) remained in 1902 . When this decrease is averaged over twenty years, the annual rate of decrease is found to be 3.8 percent. ${ }^{22} \mathrm{~A}$ similar calculation can be performed for the Moscow-born population. The 1882 census counted 196,559 persons as native-born Muscovites; over 38 percent of this group was still residing in the city twenty years later (counted in the 1902 census as "Moscow-born, aged 20 and above").

Part of the decrease in both groups was, of course, attributable to mortality. Moscow's overall mortality rate in these years, however, was around 2.8 percent per annum, and for the age group 10-50, in which most migrants were concentrated, it was much lower. ${ }^{23}$ One concludes that many individuals moved away from Moscow, and that those who had been born elsewhere were more likely to leave.

Who was entering and leaving Moscow can be determined more precisely by comparing census figures for different sosloviia. Table 3 shows the duration of residence of peasant and nonpeasant migrants counted in the 1902 census. The proportion of peasants with one year or less of residence was half again as great as that of other unprivileged sosloviia (that is, the groups whose working and living conditions most closely resembled those of peasant migrants). This pattern was reversed in the "over twenty years" group, which

22. V. Massal'skii,"Predvaritel'nye dannye perepisi 1902 goda, IV: Naselenie po semeinomu sostoianiiu," Izvestiia Moskovskoi gorodskoi dumy, 28, no. 15 (1904): 25.

23. Smertnost' naseleniia goroda Moskvy, 1872-1889 g., comp. Statisticheskii otdel Moskovskoi gorodskoi upravy (Moscow, 1891), pp. 20-22. The mortality rate for the total population in the years $1882-85$ (including foundling infants) was 28.2 per 1,000 per annum. Age-specific rates were as follows: age $10-15,5.6$ per 1,$000 ; 15-20,7$ per 1,$000 ; 20-30,11$ per 1,$000 ; 30-40,15$ per 1,$000 ; 40-50,22$ per 1,$000 ; 50-60,34$ per 1,000 . Sixty-eight percent of all migrants in the 1882 census were in the age group 10-40, as compared to 47 percent of the Moscow-born population (Perepis' Moskvy 1882 goda, no. 2 , sec. 1, p. 50 ). 
Table 3. Duration of Residence of Migrants in Moscorv, 1902 (both sexes, \%)

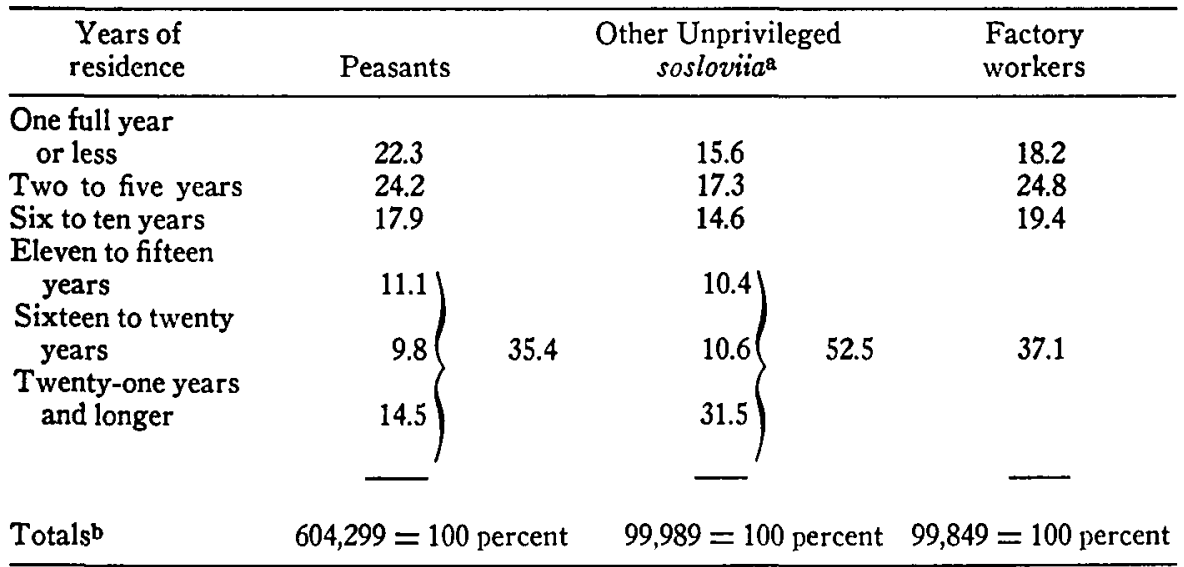

a Includes meshchane, tsekhovye, and "other unprivileged."

b Because percentages are rounded off, totals may not equal 100 percent in all cases. Source: Perepis' Moskvy 1902 g., part 1, no. 1, table 5, p. 11; no. 2, table 2, pp. 8-9 (my computation).

included 14.5 percent of all peasant migrants but 31 percent of migrants of other unprivileged sosloviia. To put it another way, peasants were 89 percent of all newly-arrived migrants, but 73 percent of the "over twenty years" group.

As the right-hand column of table 3 indicates, the proportion of newlyarrived migrants was lower among factory workers than in the total peasant population, ${ }^{24}$ but the proportion of long-term residents was only slightly higher-37.1 percent of factory workers had been living in Moscow for eleven years or more, as compared to 35.4 percent of peasants and 52.5 percent of other migrants. Peasants who moved to Moscow were more likely than nonpeasants to move away-whether or not they worked in factories.

The foregoing figures provide a number of clues to the patterns of outmigration from Moscow. Although they suggest that many peasants who migrated to Moscow did not remain there permanently, they do not indicate where the out-migrants went: Did they return to the villages or continue to work in other industrial centers? Once again, statistical sources do not provide a direct answer to our question. An indirect answer can be found, however, if the age breakdown of out-migrants can be determined. If they were mostly young and able-bodied, it is reasonable to suppose that they were going to work elsewhere. If they were older, their chances of finding work in other localities would be smaller, and the likelihood that they were returning to the countryside greater.

24. This was probably attributable to the poor economic conditions of 1901-2. 
Table 4. Age Distribution of Males (percent in each age group) in Moscow City, 1882 and 1902

\begin{tabular}{|c|c|c|c|c|c|c|c|}
\hline \multirow[b]{2}{*}{ Age } & \multicolumn{3}{|c|}{1882} & \multicolumn{4}{|c|}{1902} \\
\hline & Peasants & Meshchane & $\begin{array}{l}\text { All Non- } \\
\text { Peasants }\end{array}$ & Peasants & $\begin{array}{l}\text { Factory } \\
\text { Workers }\end{array}$ & Meshchane & $\begin{array}{l}\text { All Non- } \\
\text { Peasants }\end{array}$ \\
\hline $0-9$ & 5.1 & 15.9 & 15.9 & 9.6 & & 18.7 & 17.8 \\
\hline $10-19$ & 25.8 & 21.0 & 19.4 & 21.1 & 20.9 & 19.7 & 19.7 \\
\hline $20-29$ & 32.7 & 22.2 & 19.1 & 31.9 & 36.0 & 22.8 & 22.2 \\
\hline $30-39$ & 19.5 & 15.5 & 16.1 & 19.9 & 23.9 & 17.0 & 16.7 \\
\hline $40-49$ & 9.6 & 12.0 & 13.2 & 11.3 & 13.3 & 10.9 & 11.4 \\
\hline $50-59$ & 4.7 & 8.0 & 9.7 & 4.5 & 4.6 & 6.1 & 6.7 \\
\hline \multirow{2}{*}{$\begin{array}{l}60 \text { and } \\
\text { above }\end{array}$} & & & & & & & \\
\hline & 1.9 & 5.4 & 6.0 & 1.9 & 1.0 & 4.9 & 5.3 \\
\hline \multirow[b]{2}{*}{$\begin{array}{l}\text { Total } \\
\text { Number } \\
\text { in each } \\
\text { category }\end{array}$} & $100^{a}$ & 100 & 100 & 100 & 100 & 100 & 100 \\
\hline & 249,933 & 70,290 & 182,514 & 437,618 & 107,781 & 94,658 & 168,551 \\
\hline
\end{tabular}

a Column totals may not equal 100 percent because of rounding.

Source: Perepis' Moskoy 1882 g., no. 2, table 2, pp. 3-11; Perepis' Moskvy 1902 g., part 1, no. 1 , table 6 , pp. $12-13$; ibid., no. 2 , table 2 , pp. 2-7 (my computation).

The age distribution of Moscow's population is summarized in table 4. In 1882, the proportion of peasant males aged 50-59 was just half that of other sosloviia, and in the age group 60 and over it was less than one-third. In 1902, differences between peasants and nonpeasants were less pronounced, but table 4 leaves some doubt as to who was responsible for this change. Between 1882 and 1902, the proportion of males over the age of 50 remained constant for peasants, but declined for other sosloviia. In any event, the proportion of peasant males over age 60 was barely one-third that of other sosloviia. (Among factory workers, the proportion over age 60 was lower still, but at that age a change of occupation would be expected whether or not out-migration occurred.)

Was this disparity caused by out-migration, or could other factors have produced the same pattern? Two such factors seem possible. The first is that a constant influx of peasant migrants in the younger age brackets would reduce the proportional weight of the older group. In other words, the low proportion of peasants over age 50 might not mean that anyone was moving away, but only that many more young peasants were constantly arriving. We can check this possibility by following one age cohort from the census of 1882 to 1902 . Persons who were $30-39$ years old in 1882 would have been 50-59 in 1902; comparing peasant and nonpeasant males of these ages in the two censuses, we get the results shown in table 5 . These figures indicate that the number of persons in this age group decreased absolutely, and that the de- 
Table 5. Progression of a Single Age Cohort of Peasants and Meshchane, 18821902

\begin{tabular}{lccc}
\hline Soslovie & $\begin{array}{c}\text { Population of males } \\
\text { aged 30-39,1882 }\end{array}$ & $\begin{array}{c}\text { Population of males } \\
\text { aged 50-59, 1902 }\end{array}$ & $\begin{array}{c}1902 \text { as } \\
\text { percent of } \\
1882\end{array}$ \\
\hline Peasants & 48,913 & 19,505 & 40 \\
Meshchane & 10,984 & 5,740 & 52 \\
\hline
\end{tabular}

Source: As for table 4 above.

crease was greater among peasants than among meshchane. They suggest that the low proportion of peasants in the older age brackets was the result of an absolute decrease in their numbers, rather than a relative decrease due to the influx of younger migrants.

But this still does not prove that out-migration by older peasants occurred. A second factor which could have produced the same age distribution is a difference in rates of mortality. Perhaps the conditions under which peasants worked and lived were much worse than those of other city-dwellers, making the mortality rate significantly higher. To assess the validity of this argument, the age distribution of peasants and nonpeasants in specific occupational categories must be compared. Census data are unavailable, but data from a 1907 study of the printing trades in Moscow are well suited to this purpose. ${ }^{25}$

The study divided printers into three groups: city-born (38 percent of all workers), peasant (46 percent), and "intermediate" (16 percent), the latter term referring to peasants who did not maintain a household (khoziaistwo) in the countryside but retained some ties (for example, a land allotment). ${ }^{26}$ As table 6 indicates, the proportion over the age of 40 is lower among "intermediates" than among city-born workers, and lowest of all among workers who retained strong peasant ties. This pattern is found not only in the printing trades as a whole, but in specific occupational groups such as typesetters and bookbinders.

To summarize the foregoing discussion: A comparison of the age distribution of peasants and nonpeasants shows a disproportionately small number of the former in the age group 40 and above. This disparity cannot fully be explained by differences in the rates of in-migration or mortality of different sosloviia. Moreover, when the comparison is restricted to persons whose living and working conditions were identical, peasants are still found to be

25. A. Svavitskii and V. Sher, Ocherk polozheniia rabochikh pechatnogo dela $v$ Moskve (po dannym ankety, proizvedennoi Obshchestvom rabochikh graficheskikh iskusstv v 1907 g.) (St. Petersburg, 1909).

26. Ibid., pp. 8-9. 
Table 6. Age Distribution of Workers in Printing Trades (1907)

\begin{tabular}{|c|c|c|c|c|c|c|}
\hline \multirow[b]{2}{*}{ Occupation } & \multicolumn{6}{|c|}{ Percent of workers by age groups: } \\
\hline & Under 20 & $20-40$ & $40-45$ & $45-50$ & Over 50 & Total \\
\hline $\begin{array}{l}\text { Typesetters }{ }^{\mathrm{a}} \text { : } \\
\text { Urban } \\
\text { Intermediate } \\
\text { Peasant }\end{array}$ & $\begin{array}{r}5.4 \\
9.2 \\
10.7\end{array}$ & $\begin{array}{l}75.3 \\
84.8 \\
83.1\end{array}$ & $\begin{array}{r}10.0 \\
4.1 \\
4.8\end{array}$ & $\begin{array}{l}5.8 \\
2.0 \\
0.5\end{array}$ & $\frac{3.7}{1.0}$ & $\begin{array}{l}100 \\
100 \\
100\end{array}$ \\
\hline $\begin{array}{l}\text { Bookbinders }{ }^{\mathfrak{a}} \text { : } \\
\text { Urban } \\
\text { Intermediate } \\
\text { Peasant }\end{array}$ & $\begin{array}{l}11.5 \\
11.1 \\
10.2\end{array}$ & $\begin{array}{l}71.3 \\
77.7 \\
78.2\end{array}$ & $\begin{array}{l}9.0 \\
9.7 \\
5.3\end{array}$ & $\begin{array}{l}4.9 \\
1.4 \\
3.3\end{array}$ & $\frac{3.3}{2.9}$ & $\begin{array}{l}100 \\
100 \\
100\end{array}$ \\
\hline $\begin{array}{l}\text { All printing trad } \\
\text { Urban } \\
\text { Peasant } \\
\text { Rural }\end{array}$ & $\begin{array}{r}8.2 \\
10.1 \\
12.8\end{array}$ & $\begin{array}{l}74.2 \\
75.8 \\
77.4\end{array}$ & $\begin{array}{l}8.9 \\
7.2 \\
4.5\end{array}$ & $\begin{array}{l}5.0 \\
4.8 \\
3.6\end{array}$ & $\begin{array}{l}3.7 \\
2.4 \\
1.9\end{array}$ & $\begin{array}{l}100 \\
100 \\
100\end{array}$ \\
\hline
\end{tabular}

a Typesetters and bookbinders were the largest occupational groups in the printing trades, and hence had the least possibility of distortion by a few individuals.

Source: A. Svavitskii and V. Sher, Ocherk polozheniia rabochikh pechatnogo dela $v$ Moskve (St. Petersburg, 1909), appendix, table 1 (my calculation).

less numerous in the older group. We are left with the impression that a significant proportion of peasants departed from Moscow after age 40. It cannot be proven that they returned to their birthplaces, but this inference is consistent with evidence of workers' landholding and family ties to the countryside.

Most historians, Soviet and non-Soviet, have implicitly accepted a dichotomy between village and factory, disagreeing only in the relative importance they imputed to a "progressive" proletarian or "primitive" peasant outlook. Data in the present study tend to undermine this dichotomy. They suggest a constant two-way movement between the countryside and industrial centers-a movement which was not confined to unskilled occupations but also could include industrial veterans. In the long run, the proportion of thoroughly "citified" or "proletarianized" workers may have been increasing ; some of the data in tables 2 and 4 do seem to point in this direction. Yet other evidence (for example, workers' land allotments, as described in footnote 18) suggests that such workers were still an exceptional minority at the turn of the twentieth century.

Only a small proportion of Russia's peasant population was present in the cities and factories at any given moment, but many more had been there and returned to the countryside. Those who stayed in the factories for many years still took the opportunity to return to the countryside periodically, and in hard times the village remained a place of refuge. 
The evidence which has been considered here pertains almost entirely to the years before 1905, and takes no account of the enormous changes which occurred in city and countryside after that date. It seems doubtful, however, that the experiences and attitudes of the earlier years could be forgotten in the space of a single decade. Our sources provide little evidence for describing peasant-workers as disoriented, uprooted, unconscious, or primitive. If, as Leopold Haimson and others have suggested, ex-peasants were especially responsive to extremist slogans after 1912, the shock of transition to city and factory life was probably not the source of their militancy. 